\title{
PENETRATION EXPERIMENTS WITH LIMESTONE TARGETS AND OGIVE-NOSE STEEL PROJECTILES
}

\author{
D. J. FREW \\ Waterways Experiments Station, Vicksburg, MS 39180-6199 \\ M. J. FORRESTAL \\ Sandia National Laboratories, Albuquerque, NM 87185-0303 \\ S. J. HANCHAK \\ University of Dayton Research Institute, Dayton, OH 45469-0182
}

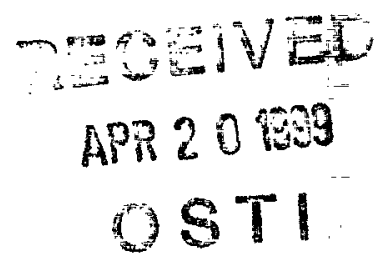

\begin{abstract}
We conducted three sets of depth-of-penetration experiments with limestone targets and 3.0 caliber-radius-head (CRH), ogive-nose steel rod projectiles. The limestone targets had a nominal unconfined compressive strength of $60 \mathrm{MPa}$, a density of $2.31 \mathrm{~kg} / \mathrm{m}^{3}$, a porosity of 15 percent, and a water content less than 0.4 percent. The ogive-nose rod projectiles with length-to-diameter ratios of ten were machined from $4340 R_{c} 45$ and Aer Met $100 R_{c} 53$ steel, round stock and had diameters and masses of $7.1 \mathrm{~mm}, 0.020 \mathrm{~kg} ; 12.7 \mathrm{~mm}, 0.117 \mathrm{~kg}$; and $25.4 \mathrm{~mm}, 0.931 \mathrm{~kg}$. Powder guns or a two-stage, light-gas gun launched the projectiles at normal impacts to striking velocities between 0.4 and $1.9 \mathrm{~km} / \mathrm{s}$. For the $4340 \mathrm{R}_{\mathrm{c}} 45$ and Aer Met $100 \mathrm{R}_{\mathrm{c}} 53$ steel projectiles, penetration depth increased as striking velocity increased to a striking velocity of 1.5 and 1.7 $\mathrm{km} / \mathrm{s}$, respectively. For larger striking velocities, the projectiles deformed during penetration without nose erosion, deviated from the shot line, and exited the sides of the target. We also developed an analytical penetration equation that described the target resistance by its density and a strength parameter determined from depth of penetration versus striking velocity data.
\end{abstract}




\section{DISCLAIMER}

This report was prepared as an account of work sponsored by an agency of the United States Government. Neither the United States Government nor any agency thereof, nor any of their employees, make any warranty, express or implied, or assumes any legal liability or responsibility for the accuracy, completeness, or usefulness of any information, apparatus, product, or process disclosed, or represents that its use would not infringe privately owned rights. Reference herein to any specific commercial product, process, or service by trade name, trademark, manufacturer, or otherwise does not necessarily constitute or imply its endorsement, recommendation, or favoring by the United States Government or any agency thereof. The views and opinions of authors expressed herein do not necessarily state or reflect those of the United States Government or any agency thereof. 


\section{DISCLAIMER}

Portions of this document may be illegible in electronic image products. Images are produced from the best available original document. 


\section{Introduction}

Several authors have written review articles that discuss the many analytical, computational, and experimental methods used to study the broad field of penetration mechanics (Backman and Goldsmith, 1978; Anderson and Bodner, 1988; Hohler and Stilp, 1990; Recht, 1990; Corbett, Reid, and Johnson, 1996). The responses of the projectiles and targets depend strongly on the problem geometry, materials, and impact conditions. Because many penetration mechanisms are possible, experimental observations usually precede and guide analytical or computational models. For this study, post-test target observations showed a conical entry crater with a depth of two or more projectile diameters followed by a circular penetration channel or tunnel with nearly the projectile diameter. For recent penetration studies with 6061-T6511 aluminum targets (Warren and Forrestal, 1998; Piekutowski, Forrestal, Poormon, and Warren, in press), we could obtain post-test radiographs of the penetration channels. However, we made post-test observations of the limestone penetration channels only after the targets were split with the techniques used by stone masons. The projectiles recovered from the targets had small mass losses due to abrasion, but the overall nose shapes prior to and after penetration looked very similar. We previously observed similar post-test, target channels and abraded projectiles with our studies on concrete targets (Forrestal, Frew, Hanchak, and Brar, 1996; Frew, Hanchak, Green, and Forrestal, 1998). However, the concrete targets abraded the nose tips more severely than the limestone targets.

Based on penetration data sets with three projectile scales, we propose an analytical penetration equation that describes the target resistance by its density and a target strength parameter determined from penetration depth versus striking velocity data. Our limestone penetration equation is similar to that previously derived for concrete targets (Forrestal, Altman, 
Cargile, and Hanchak, 1994). However, for limestone targets, we observed a noticeable decrease in the target resistance parameter as the projectile diameters increased. So for the limestone targets, the target resistance parameter is equal to a constant term plus a term that depends on the projectile diameter. We speculate that this penetration equation will be reasonably accurate for larger scale projectiles, but data from much more expensive field tests must be obtained to confirm our speculation.

The limestone targets were quarried and cut by the Elliot Stone Company.* In the rock mechanics literature, this particular limestone is often called Salem, Indiana, or Bedford limestone. For this study, we conducted unconfined compressive tests and some triaxial compression tests on samples cored from representative blocks and from individual targets prior to penetration. Material properties from our targets are nearly the same as those reported by Fossum, Senseny, Pfeifle, and Mellegard (1995).

As previously mentioned, our penetration equation contains a target strength constant that is determined from penetration depth versus striking velocity data. While this methodology provides an accurate and convenient engineering equation, the detailed response mechanisms for the target are not modeled. The authors are not aware of any rigorous target models for rock penetration problems, but Lagrangian computational models that use adaptive meshing techniques have shown promise for brittle ceramic targets (Ortiz, 1966; Camacho and Ortiz, 1997). Detailed computational approaches that model target responses also require a broad array of quasi-static and dynamic material properties data. For limestone, examples of some materials experiments and data include (1) quasi-static, triaxial compression experiments (Fossum, Senseny, Pfeifle, and Mellegard, 1995), (2) split Hopkinson bar experiments (Green and Perkins, 1968; Lindholm, 
Yeakley, and Nagy, 1974; and Lipkin, Grady, and Campbell, 1977), (3) plane shock wave studies (Larson and Anderson, 1979), (4) dynamic tensile failure with planar-impact techniques (Grady and Hollenbach, 1979; Ahrens and Rubin, 1993), and (5) compression-shear loading with plate impact experiments (Aidun and Gupta, 1995). Data from other experimental techniques may also be required for a careful target analysis.

In the next sections, we develop the penetration model, describe the experiments, and present our results and conclusions.

* Elliot Stone Company, 3326 Mitchell Road, Bedford, IN 47421. 


\section{Penetration Model}

For both limestone and concrete targets, post-test observations showed a conical entry crater with a depth of two or more projectile diameters followed by a circular channel or tunnel with nearly the projectile diameter. The limestone penetration equations are similar to the previously published concrete penetration equations. From Forrestal, Altman, Cargile, and Hanchak (1994), depth of penetration $P$ for an ogive-nose projectile and a concrete target is given by

$$
\begin{gathered}
P=\frac{m}{2 \pi a^{2} \rho N} \ln \left(1+\frac{N \rho V_{1}^{2}}{\mathrm{R}}\right)+4 a, \quad P>4 a \\
N=\frac{8 \psi-1}{24 \psi^{2}}, \quad V_{1}^{2}=\frac{m V_{\mathrm{S}}^{2}-4 \pi a^{3} \mathrm{R}}{m+4 \pi a^{3} N \rho}
\end{gathered}
$$

in which the ogive-nose rod projectile is described by mass $m$, shank radius $a$, and caliber-radiushead $\psi$. The target is described by density $\rho$ and the target strength constant R. The strength constant is determined from

$$
\mathrm{R}=\frac{N \rho V_{s}^{2}}{\left(1+\frac{4 \pi \mathrm{a}^{3} N \rho}{m}\right) \exp \left[\frac{2 \pi a^{2}(P-4 a) N \rho}{m}\right]-1}
$$

where $V_{\mathrm{s}}$ is striking velocity. For a set of experiments, we hold all parameters constant and vary striking velocity. From each experiment, we measure striking velocity $V_{\mathrm{s}}$ and penetration depth $P$, so $\mathrm{R}$ can be determined from (2) for each experiment. We then take the average value of $\mathrm{R}$ from each experiment in the data set and compare the prediction from (1) with the individual measured values of $V_{\mathrm{s}}$ and $P$. For the concrete penetration equations (Forrestal, Altman, Cargile, and 
Hanchak, 1994), we found it convenient to let $\mathrm{R}=S f_{c}^{\prime}$ where $f_{c}^{\prime}$ is the unconfined compressive strength of the concrete target and $S$ is a dimensionless parameter.

Frew, Hanchak, Green, and Forrestal (1998) showed that for concrete targets with nearly equal unconfined compressive strengths, ogive-nose steel rod projectiles had nearly the same constant value of $\mathrm{R}=S f_{c}^{\prime}$ for 20.3- and 30.5-mm-diameter projectiles with a length-to-diameter ratio of ten. However, for this study with limestone targets, ogive-nose steel rod projectiles with 7.1, 12.7, and 25.4-mm-diameters and a length-to-diameter of ten have values of $R=913,787$, and $693 \mathrm{MPa}$, respectively. Thus, the target resistance decreases as projectile shank diameter increases. Warren and Forrestal (1998) studied the effects of strain hardening and strain-rate effects on the penetration of aluminum targets. Results from that study show the same dependence of projectile diameter on target strength. Guided by the models in Warren and Forrestal (1998), we found that for these limestone targets

$$
\mathrm{R}=K+k\left(2 a_{o} / 2 a\right)
$$

in which $K$ and $k$ are constants obtained from data fits, $2 a_{o}$ is a reference projectile diameter, and $2 a$ is the projectile diameter. We show later that with $K=607 \mathrm{MPa}, k=86 \mathrm{MPa}$, and $2 a_{o}=$ $25.4 \mathrm{~mm}$, we recover the measured values of $\mathrm{R}$ for each of the three data sets.

In summary, the procedure used to calculate $\mathrm{R}$ from penetration depth data for a fixed projectile is the same for concrete or limestone targets. However, for limestone targets, $R$ depends on the projectile shank diameter. Thus, we can use the penetration equations (1a and $1 \mathrm{~b}$ ) for limestone when $\mathrm{R}$ is given by (3). 


\section{Experiments}

We conducted three sets of penetration experiments (a total of 30 experiments) with ogivenose, steel rod projectiles and limestone targets. All projectiles had a total length-to-diameter ratio of ten and 3.0 caliber-radius-head $(\mathrm{CRH})$ nose shapes. The shank diameters and masses for each of the three sets of experiments were $7.1 \mathrm{~mm}, 0.020 \mathrm{~kg} ; 12.7 \mathrm{~mm}, 0.117 \mathrm{~kg}$; and $25.4 \mathrm{~mm}$, $0.931 \mathrm{~kg}$.

Limestone Targets. The limestone targets were quarried and cut by the Elliot Stone Company of Bedford, Indiana. We obtained the targets in three batches from nearby sites. Nominal material properties for the three target batches given in Table 1 show minimal variations among the batches.

Figure 1 shows data from triaxial material tests for samples from batch 3 . For these experiments a 51-mm-diameter, 108-mm-long cylinder of limestone is loaded with two stress paths: isotropic compression followed by triaxial shear (Farmer, 1983, and Jaeger and Cook, 1979). The limestone cylinders are loaded with axial stress $\sigma_{a}$ and radial stress $\sigma_{r}$. For the triaxial data shown in Fig. 1, the limestone cylinders are first loaded with isotropic compression, $\sigma_{a}=\sigma_{r}$, and then the axial stress $\sigma_{a}$ is increased while the radial stress $\sigma_{r}$ is held constant. Figure 1 shows plots of principal stress difference (true stress), $\sigma_{a}-\sigma_{r}$, versus axial strain (engineering strain) for $\sigma_{r}=20,50$, and $100 \mathrm{MPa}$. For a radial stress or confining pressure of $20 \mathrm{MPa}$, the principal stress difference, $\sigma_{a}-\sigma_{r}$, reaches a maximum at about $96 \mathrm{MPa}$, and then the sample fractures. For radial stresses of 50 and $100 \mathrm{MPa}$, the sample deforms with a ductile response. The brittle to ductile transition confining pressure is about $50 \mathrm{MPa}$. 
The 12.7-mm-diameter, $0.117 \mathrm{~kg}, 3.0 \mathrm{CRH}$ projectiles. Our first set of experiments was conducted with steel projectiles machined from $4340 R_{c} 45$ (Brown, Mindlin, and Ho, 1996) round stock. Figure 2 shows the projectile geometry, and for this set of experiments $2 a=12.7$ $\mathrm{mm}, L=106 \mathrm{~mm}$, and $l=21 \mathrm{~mm}$. The limestone target impact surface was $0.51-\mathrm{m}$-square, and the target lengths and other data are given in Table 2 . The sides and bottom of the targets were surrounded by 0.10 -m-thick concrete placed between a steel form and the limestone. Six unconfined compressive tests were conducted with 51-mm-diameter, 107-mm-long samples cored from a representative limestone block from batch 1 and the average strength was $\sigma_{c f}=60 \mathrm{MPa}$.

A 32-mm-diameter powder gun launched the $0.117 \mathrm{~kg}$ projectiles to the striking velocities recorded in Table 2. An additional experiment was conducted at $V_{\mathrm{s}}=1605 \mathrm{~m} / \mathrm{s}$, but the trajectory was curved and the projectile exited the side of the target at a depth of about $0.65 \mathrm{~m}$. The projectiles were fitted with sabots and obturators that separated from the projectiles prior to impact. Four laser diode systems measured striking velocities and orthogonal radiographs measured pitch and yaw angles. The target resistance $R$ was calculated from (2) for each experiment and recorded in Table 2. The average target resistance parameter for this set of experiments is $R=787 \mathrm{MPa}$.

The 7.1-mm-diameter, $0.020 \mathrm{~kg}, 3.0 \mathrm{CRH}$ projectiles. Our second set of experiments was conducted with steel projectiles machined from both $4340 R_{c} 45$ and Aer Met $100 R_{c} 53$ (Dahl, 1991) round stock. Figure 2 shows the projectile geometry, and for this set of experiments $2 a=$ $7.11 \mathrm{~mm}, L=59.3 \mathrm{~mm}$, and $l=11.8 \mathrm{~mm}$. A $20-\mathrm{mm}$-powder gun launched the $0.020 \mathrm{~kg}$ projectiles to striking velocities of $1230 \mathrm{~m} / \mathrm{s}$. For the larger striking velocities recorded in Table 3, a two-stage, 50/20 mm, light-gas gun launched the projectiles. The same target 
geometries and ballistics measurements as those described for the $12.7-\mathrm{mm}$-diameter, $0.117 \mathrm{~kg}$ projectiles were used for this set of experiments.

For this second set of experiments, we performed unconfined compressive tests on two samples cored from the targets. The compressive strengths listed in Table 3 are the average of two, unconfined compression tests conducted with 50-mm-diameter, 107-mm-long cores. In addition, we conducted penetration experiments from both batch 1 and batch 3 limestone targets to compare results from the two batches. We show later negligible differences in the penetration data from both batches. The average target resistance parameter for this set of experiments is $\mathrm{R}=913 \mathrm{MPa}$.

We also conducted an experiment with a $4340 \mathrm{R}_{\mathrm{c}} 45$ projectile at $V_{\mathrm{s}}=1649 \mathrm{~m} / \mathrm{s}$. That projectile severely bent and turned within the target. Table 3 shows two experiments conducted with Aer Met $100 R_{c} 53$ projectiles. Shot 4-1846 with a striking velocity of $1674 \mathrm{~m} / \mathrm{s}$ had a nearly straight trajectory. We then conducted experiments at $V_{\mathrm{s}}=1749,1826$, and $1863 \mathrm{~m} / \mathrm{s}$ with Aer Met $100 R_{c} 53$ projectiles and these projectiles severely bent and turned within the targets. Piekutowski, Forrestal, Poormon, and Warren (in press) discusses in detail the better performance of the Aer Met $100 R_{c} 53$ projectiles.

The 25.4 -mm-diameter, $0.931 \mathrm{~kg}, 3.0 \mathrm{CRH}$ projectiles. Our third set of experiments was conducted with steel projectiles machined from $4340 R_{c} 45$ round stock. Figure 2 shows the projectile geometry, and for this set of experiments $2 a=25.4 \mathrm{~mm}, L=212 \mathrm{~mm}$, and $l=42 \mathrm{~mm}$. The limestone target impact surface was 1.02-m-square and the target lengths are given in Table 4. An $83-\mathrm{mm}$ powder gun launched the $0.931 \mathrm{~kg}$ projectiles to the striking velocities recorded in Table 4. The same experimental methods used for the other data sets were also used to obtain the 
results given in Table 4. Data in Table 4 were limited to $V_{\mathrm{s}}=1177 \mathrm{~m} / \mathrm{s}$ because of the size and mass of the targets. The average value of $R$ for this set of experiments was $R=693 \mathrm{MPa}$. 


\section{Results and Discussion}

As previously discussed, post-test target observation for the experiments summarized in Tables 2,3 , and 4 showed a conical entry crater with a depth of two or more projectile diameters followed by a circular penetration tunnel with nearly the projectile diameter. However, we made post-test observations only after the targets were split with the techniques used by stone masons. Figure 3 shows post-test photographs of the 25.4-mm-diameter projectiles, and mass losses are given in Table 4. These recovered projectiles lost mass due to abrasion, but the nose shapes prior to and after penetration have similar shapes. Post-test projectiles from the other data sets (Tables 2 and 3) had shapes similar to those shown in Fig. 3.

Figure 4 shows depth of penetration $P$ versus striking velocity $V_{\mathrm{s}}$ for the data in Tables 2,3 ,

and 4. For the model, we use the average value of $\mathrm{R}$ calculated from (2) for the experiments in each data set. For the 7.1, 12.7, and 25.4-mm-diameter projectiles the average target resistance parameter is $\mathrm{R}=913,787$, and $693 \mathrm{MPa}$, respectively. As discussed in the Penetration Model section, these diameter dependent results suggest a strain-rate effect for the target resistance. For projectile diameters not tested in this study, we recommend (3) be used to calculate R. Equation (3) with $K=607 \mathrm{MPa}, k=86 \mathrm{MPa}$, and $2 a_{o}=25.4 \mathrm{~mm}$ recover the measured values of $\mathrm{R}$ from each of the three data sets. We speculate that the penetration equations $(1,2$, and 3$)$ for this limestone target will be reasonably accurate for larger scale projectiles, but data from much more expensive field tests with larger diameter projectiles must be obtained to confirm our speculation. 


\section{Summary}

We conducted sets of penetration experiments into limestone targets with three scales of geometrically similar projectiles. The ogive-nose rod projectiles with a length-to-diameter ratio of ten were machined from $4340 R_{c} 45$ and Aer Met $100 R_{c} 53$ steel, round stock and had diameters and masses of $7.1 \mathrm{~mm}, 0.020 \mathrm{~kg} ; 12.7 \mathrm{~mm}, 0.117 \mathrm{~kg}$; and $25.4 \mathrm{~mm}, 0.931 \mathrm{~kg}$. For the $4340 \mathrm{R}_{\mathrm{c}} 45$ and Aer Met $100 R_{c} 53$ steel projectiles, penetration depth increased as striking velocity increased to 1500 and $1700 \mathrm{~m} / \mathrm{s}$, respectively. For larger striking velocities, the projectiles bent during penetration without nose erosion, deviated from the shot line, and exited the sides of the target or turned severely in the target.

Based on data sets with these three projectile scales, we present an analytical penetration equation that describes the target resistance by its density and a target strength parameter that is determined from penetration depth versus striking velocity data. We show that the target resistance parameter depends on the projectile shank diameter and present an equation that describes this projectile diameter dependence. We speculate that the penetration equations for this limestone target will give accurate predictions for larger scale projectiles, but data from much more expensive field tests with larger diameter projectiles must be obtained to confirm our speculation.

Acknowledgements-This work was supported by the United States Department of Energy under

Contract DE-AC04-94AL85000, the Joint DoD/DOE Munitions Technology Development Program, and the U.S. Army Corps of Engineers Hardened Structures Research Programs (AT22 and AT40). 


\section{References}

Ahrens, T. J., and Rubin, A. M., 1993, "Impact-induced tensional failure in rock," Journal of Geophysical Research, Vol. 98, No. E1, pp. 1185-1203.

Aidun, J. B., and Gupta, Y. M., 1995, "Shear and compression waves in shocked calcium carbonate," Journal of Geophysical Research, Vol. 100, No. B2, pp. 1955-1980.

Anderson, C. E., and Bodner, S. R., 1988, "Ballistic impact: the status of analytical and numerical modeling," Int. J. Impact Engng., Vol. 7, pp. 9-35.

Backman, M. E., and Goldsmith, W., 1978, "The mechanics of penetration of projectiles into targets," Int. J. Eng. Sci., Vol. 16, pp. 1-99.

Brown, W. F., Mindlin, H., and Ho, C. Y., 1996, Aerospace Structural Metals Handbook, Vol. 1, Code 1206, CINDAS/USAF CRDA Handbooks Operation, Purdue University, West Lafayette, IN 47907-1293.

Camacho, G. T., and Ortiz, M., 1997, "Adaptive Lagrangian modelling of ballistic penetration of metallic targets," Comput. Methods Appl. Engng., 142, pp. 269-301.

Corbett, G. G., Reid, S. R., and Johnson, W., 1996, "Impact loading of plates and shells by freeflying projectiles: a review," Int. J. Impact Engng., Vol. 18, pp. 141-230.

Dahl, J., 1991, "Aer Met 100 - an advanced steel for the aerospace industry," Advanced Materials Technology International, pp. 40-45.

Farmer, I., 1983, Engineering Behavior of Rocks, $2^{\text {nd }}$ edition, Chapman and Hall, N.Y.

Forrestal, M. J., Altman, B. S., Cargile, J. D., and Hanchak, S. J., 1994, "An empirical equation for penetration depth of ogive-nose projectiles into concrete targets," Int. J. Impact Engng., Vol. 15 , No. 4, pp. 395-405.

Forrestal, M. J., Frew, D. J., Hanchak, S. J., and Brar, N. S., 1996, "Penetration of grout and concrete targets with ogive-nose steel projectiles," Int. J. Impact Engng., Vol. 18, No. 5, pp. $465-476$.

Fossum, A. F., Senseny, P. E., Pfeifle, T. W., and Mellegard, K. D., 1995, "Experimental determination of probability distributions for parameters of a salem limestone cap plasticity model," Mechanics of Materials 21, pp. 119-137.

Frew, D. J., Hanchak, S. J., Green, M. L., and Forrestal, M. J., 1998, "Penetration of concrete targets with ogive-nose steel rods," Int. J. Impact Engng., Vol. 21, No. 6, pp. 489-497. 
Grady, D. E., and Hollenbach, R. E., 1979, "Dynamic fracture strength of rock," Geophysical Research Letters, Vol. 6, No. 2, pp. 73-76.

Green, S. J., and Perkins, R. D., 1968, "Uniaxial compression tests at varying strain rates on three geologic materials," Proc. $10^{\text {th }}$ Symp. Rock Mechanics, Inst. Mining Metallurgical and Petroleum Engrs., edited by K.E. Gray, pp. 35-54.

Hohler, V., and Stilp, A. J., 1990, "Long-Rod Penetration Mechanics," High Velocity Impact Dynamics, Chapter 5, J. A. Zukas (Ed.), John Wiley and Sons, Inc., New York, N.Y.

Jaeger, J. C., and Cook, N. G. W., 1979, Fundamentals of Rock Mechanics, $3^{\text {rd }}$ edition, Chapman and Hall, N.Y.

Larson, D. B., and Anderson, G. D., 1979, "Plane shock wave studies of porous geological media," Journal of Geophysical Research, Vol. 84, No. B9, pp. 4592-4600.

Lindholm, U. S., Yeakley, L. M., and Nagy, A., 1974, "The dynamic strength and fracture properties of Dresser Basalt," Int. J. Rock Mech. Min. Sci. \& Geomech. Abstr., Vol. II, pp. 181191.

Lipkin, J., Grady, D. E., and Campbell, J. D., 1977, "Dynamic flow and fracture of rock in pure shear," Proc. $18^{\text {th }}$ U.S. Symp. Rock Mechanics, Colorado School of Mines Press, edited by F. Wang and G. B. Clark, pp. 3 B2-1, 3 B2-7.

Ortiz, M., 1996, "Computational micromechanics," Computational Mechanics 18, pp. 321-338.

Piekutowski, A. J., Forrestal, M. J., Poormon, K. L., and Warren, T. L., in press, "Penetration of 6061-T6511 aluminum targets by ogive-nose steel projectiles with striking velocities between 0.5 and $3.0 \mathrm{~km} / \mathrm{s}$," Int. J. Impact Engng.

Recht, R., 1990, "High Velocity Impact Dynamics: Analytical Modeling of Plate Penetration Dynamics," High Velocity Impact Dynamics, Chapter 7, J. A. Zukas (Ed.), John Wiley and Sons, Inc., New York, N.Y.

Warren, T. L., and Forrestal, M. J., 1998, "Effects of strain hardening and strain-rate sensitivity on the penetration of aluminum targets with spherical-nosed rods," Int. J. Solids Structures, Vol. 35, Nos. 28-29, pp. 3737-3753. 
Table 1. Nominal material properties for the limestone targets.

\begin{tabular}{ccccc}
\hline $\begin{array}{c}\text { Batch } \\
\text { number }\end{array}$ & $\begin{array}{c}\text { Density } \\
\rho\left(\mathrm{Mg} / \mathrm{m}^{3}\right)\end{array}$ & $\begin{array}{c}\text { Water } \\
\mathrm{W}(\%)\end{array}$ & $\begin{array}{c}\text { Porosity } \\
\mathrm{n}(\%)\end{array}$ & $\begin{array}{c}\text { Compressive } \\
\text { strength } \\
\sigma_{\mathrm{cf}}(\mathrm{MPa})\end{array}$ \\
\hline 1 & 2.32 & 0.16 & 14.4 & 58 \\
3 & 2.30 & 0.16 & 15.1 & 63 \\
4 & 2.31 & 0.11 & 14.8 & 61 \\
\hline
\end{tabular}

Table 2. Penetration data for the 12.7-mm-diameter, $4340 \quad R_{c} 44-45,0.117 \mathrm{~kg}$, 3.0 CRH projectiles. For pitch and yaw: $D=$ down, $U=u p, R=$ right, $L=$ left.

\begin{tabular}{ccclccc}
\hline $\begin{array}{c}\text { Shot, Batch } \\
\text { number }\end{array}$ & $\begin{array}{c}\text { Target } \\
\text { length } \\
(\mathrm{m})\end{array}$ & $\begin{array}{c}\text { Striking } \\
\text { velocity } \\
\mathrm{V}_{\mathrm{s}}(\mathrm{m} / \mathrm{s})\end{array}$ & $\begin{array}{c}\text { Pitch, yaw } \\
(\mathrm{deg})\end{array}$ & $\begin{array}{c}\text { Penetratio } \\
\mathrm{n} \mathrm{depth} \\
\mathrm{P}(\mathrm{m})\end{array}$ & $\begin{array}{c}\text { Projectile mass } \\
\text { loss } \\
(\%)\end{array}$ & $\begin{array}{c}\mathrm{R} \\
\text { (MPa) }\end{array}$ \\
\hline $1-0370,1$ & 0.61 & 459 & $1.9 \mathrm{D}, 3.0 \mathrm{~L}$ & 0.141 & 0.16 & 733 \\
$1-0371,1$ & 0.61 & 608 & $1.0 \mathrm{U}, 1.0 \mathrm{R}$ & 0.232 & 0.24 & 734 \\
$1-0372,1$ & 0.91 & 853 & 0,0 & 0.362 & 0.96 & 875 \\
$1-0377,1$ & 0.91 & 956 & $0,0.3 \mathrm{~L}$ & 0.523 & 1.29 & 719 \\
$1-0373,1$ & 0.91 & 1134 & $1.0 \mathrm{U}, 1.9 \mathrm{R}$ & 0.562 & 2.59 & 930 \\
$1-0376,1$ & 1.22 & 1269 & 0,0 & 0.812 & 3.87 & 745 \\
$1-0375,1$ & 1.22 & 1404 & $0,0.7 \mathrm{R}$ & 0.924 & 5.25 & 775 \\
$1-0374,1$ & 1.22 & 1502 & $0.7 \mathrm{U}, 0$ & 1.017 & 5.90 & 783 \\
\hline
\end{tabular}

Table 3. Penetration data for the 7.1-mm-diameter, $4340 R_{c} 44-46$ or Aer Met $100 R_{c} 53$ (Shots 4-1847 and 4-1846), 0.0205 kg, 3.0 CRH projectiles. For pitch and yaw: $\mathrm{D}=$ down, $\mathrm{U}=$ up, $\mathrm{R}=$ right, $\mathrm{L}=$ left.

\begin{tabular}{ccclcccc}
\hline $\begin{array}{c}\text { Shot, Batch } \\
\text { number }\end{array}$ & $\begin{array}{c}\text { Target } \\
\text { length } \\
(\mathrm{m})\end{array}$ & $\begin{array}{c}\text { Striking } \\
\text { velocity } \\
\mathrm{V}_{\mathrm{s}}(\mathrm{m} / \mathrm{s})\end{array}$ & $\begin{array}{c}\text { Pitch, yaw } \\
(\mathrm{deg} .)\end{array}$ & $\begin{array}{c}\text { Penetratio } \\
\mathrm{n} \text { depth } \\
\mathrm{P}(\mathrm{m})\end{array}$ & $\begin{array}{c}\text { Projectile mass } \\
\text { loss } \\
(\%)\end{array}$ & $\begin{array}{c}\text { Compressive } \\
\mathrm{R}\end{array}$ & $\begin{array}{c}\text { strength } \\
\sigma_{\mathrm{cf}} \\
(\mathrm{MPa})\end{array}$ \\
\hline $1-0422,3$ & 0.30 & 497 & $0,0.75 \mathrm{R}$ & 0.067 & 0.34 & 1033 & \\
$1-0418,3$ & 0.61 & 597 & $0.5 \mathrm{U}, 0$ & 0.105 & 0.34 & 895 & 64.7 \\
$1-0419,3$ & 0.61 & 787 & $0,1.25 \mathrm{R}$ & 0.165 & 0.78 & 937 & \\
$1-0420,3$ & 0.61 & 1037 & $0.75 \mathrm{U}, 0.5 \mathrm{R}$ & 0.271 & 2.11 & 927 & \\
$4-1835,3$ & 1.02 & 1365 & $2.0 \mathrm{D}, 1.6 \mathrm{R}$ & 0.430 & 4.90 & 926 & 58.2 \\
$4-1836,3$ & 1.02 & 1516 & $0.9 \mathrm{U}, 1.1 \mathrm{R}$ & 0.516 & 7.34 & 903 & \\
& & & & & & & \\
$1-0439,1$ & 0.46 & 795 & $0.5 \mathrm{U}, 0$ & 0.178 & 0.83 & 877 & 60.1 \\
$1-0440,1$ & 0.61 & 1060 & $0.25 \mathrm{U}, 0.5 \mathrm{R}$ & 0.294 & 2.49 & 877 & 60.3 \\
$1-0441,1$ & 0.61 & 1230 & $0,0.25 \mathrm{R}$ & 0.392 & 3.76 & 837 & 55.7 \\
$4-1845,1$ & 1.02 & 1340 & $1.75 \mathrm{D}, 1.0 \mathrm{~L}$ & 0.437 & 4.84 & 870 & 57.5 \\
& & & & & & & \\
$4-1847,3$ & 1.02 & 1266 & $1.0 \mathrm{D}, 1.5 \mathrm{R}$ & 0.379 & 4.59 & 925 & 63.8 \\
$4-1846,3$ & 1.02 & 1674 & $0.5 \mathrm{U}, 0$ & 0.581 & 10.85 & 944 & 63.9 \\
\hline
\end{tabular}


Table 4. Penetration data for the 25.4-mm-diameter, $4340 R_{c} 45-46,0.931 \mathrm{~kg}, 3.0 \mathrm{CRH}$ projectiles. For pitch and yaw: $D=$ down, $U=$ up, $R=$ right, $L=$ left.

\begin{tabular}{ccclcccc}
\hline $\begin{array}{c}\text { Shot, Batch } \\
\text { number }\end{array}$ & $\begin{array}{c}\text { Target } \\
\text { length } \\
(\mathrm{m})\end{array}$ & $\begin{array}{c}\text { Striking } \\
\text { velocity } \\
\mathrm{V}_{\mathrm{s}}(\mathrm{m} / \mathrm{s})\end{array}$ & $\begin{array}{c}\text { Pitch, yaw } \\
(\mathrm{deg})\end{array}$ & $\begin{array}{c}\text { Penetration } \\
\text { depth } \\
\mathrm{P}(\mathrm{m})\end{array}$ & $\begin{array}{c}\text { Projectile } \\
\text { mass loss } \\
(\%)\end{array}$ & $\begin{array}{c}\mathrm{R} \\
\mathrm{MPa})\end{array}$ & $\begin{array}{c}\text { Compressive } \\
\text { strength } \\
\sigma_{\mathrm{cf}} \\
(\mathrm{MPa})\end{array}$ \\
\hline LROD99-1, 4 & 0.61 & 407 & $0.4 \mathrm{D}, 0.5 \mathrm{~L}$ & 0.26 & 0 & 617 & 56.2 \\
LROD99-2,4 & 0.76 & 566 & $0.6 \mathrm{U}, 0$ & 0.39 & 0.1 & 769 & 61.9 \\
LROD99-3, 4 & 1.07 & 800 & $0.6 \mathrm{D}, 0.1 \mathrm{~L}$ & 0.79 & 0.3 & 693 & 66.7 \\
LROD99-6, 4 & 1.52 & 917 &,$- 0.3 \mathrm{R}$ & 1.02 & 1.1 & 681 & 59.8 \\
LROD99-7, 4 & 1.98 & 1177 & $0,0.3 \mathrm{R}$ & 1.50 & 2.8 & 705 & 61.2 \\
\hline
\end{tabular}




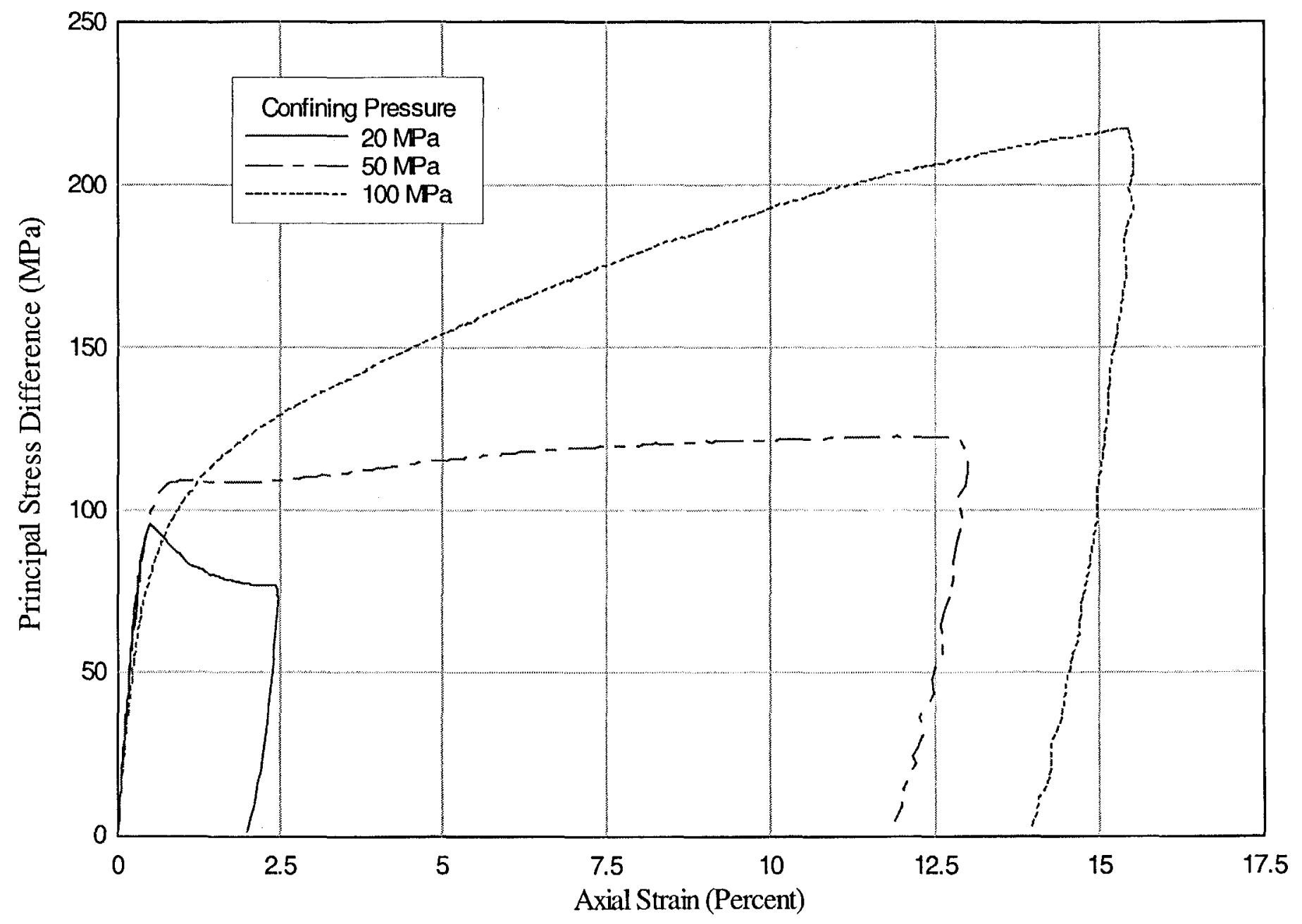

Figure 1. Batch 3 limestone triaxial compression data 


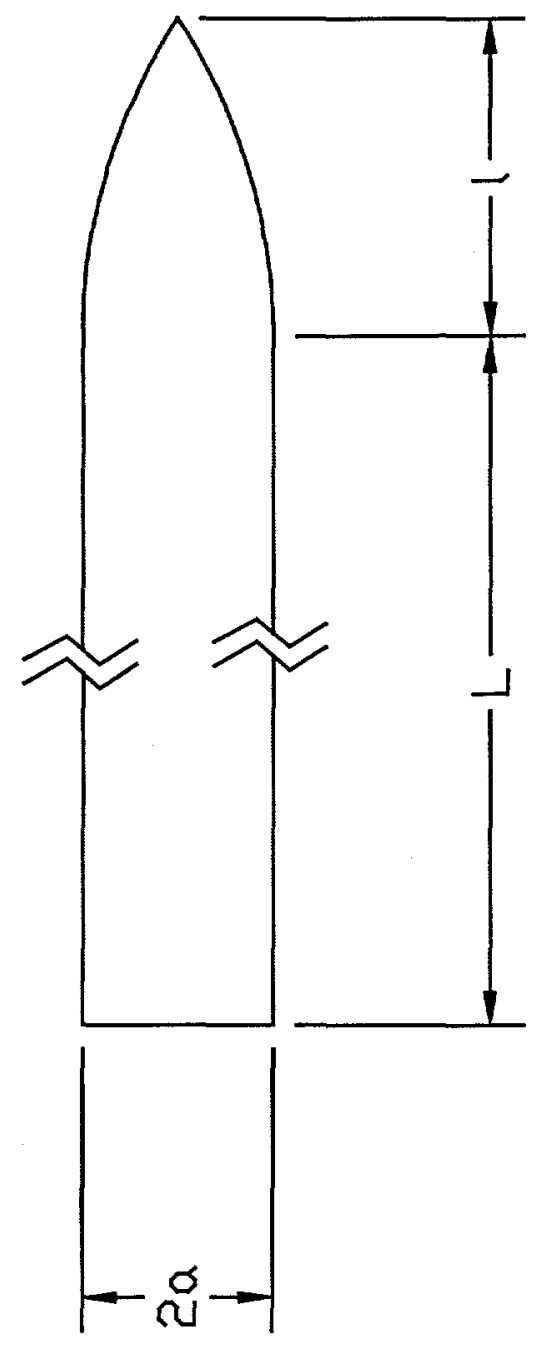

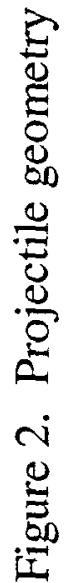




\section{UNFIRED}

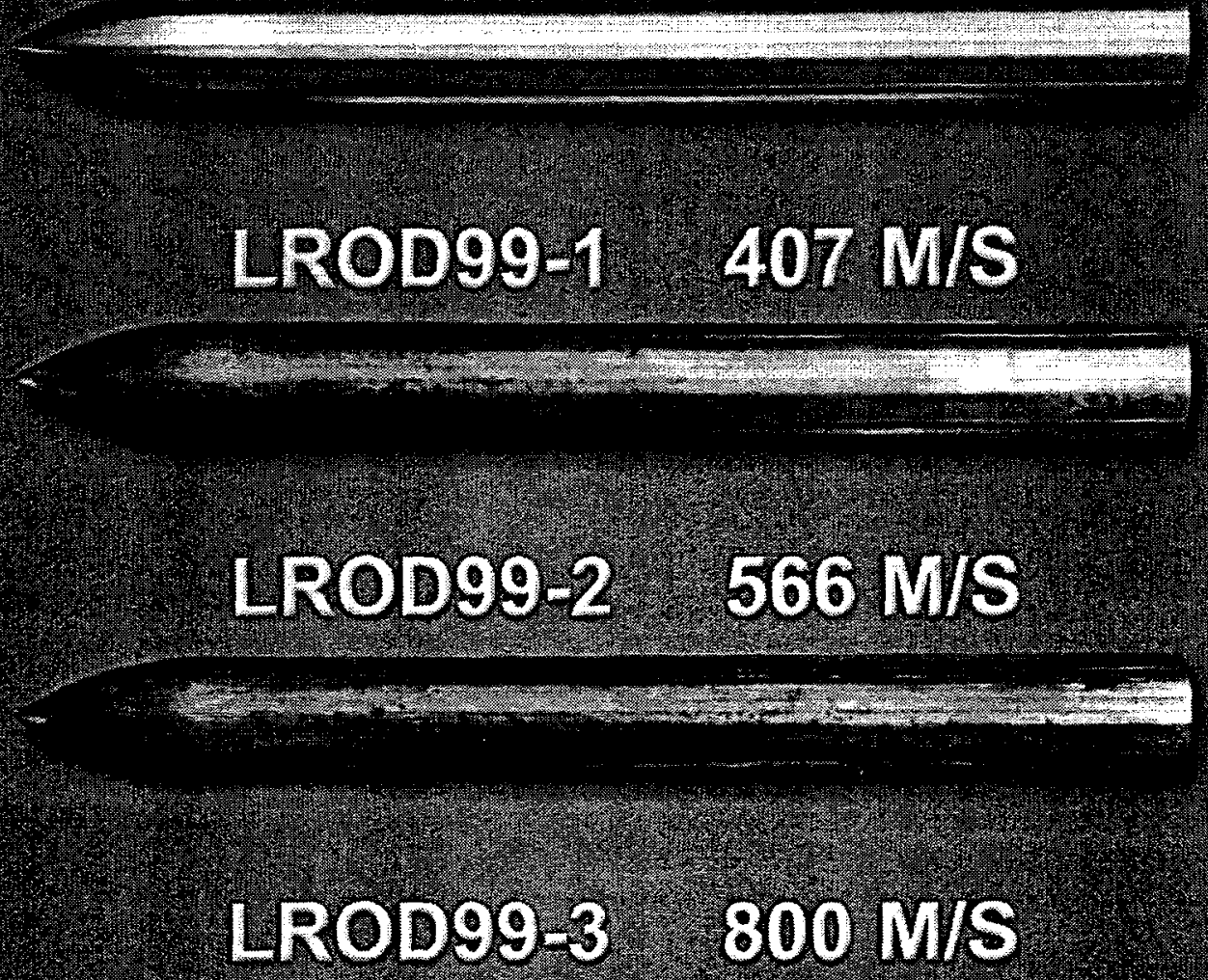

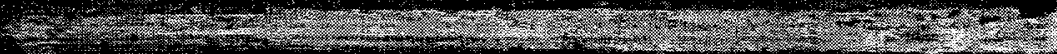

LROD99-6 917 WIS

\section{LROD99-7 1177 MIS}

Figure 3. Post-test photographs of the 25.4-mm-diameter projectiles 


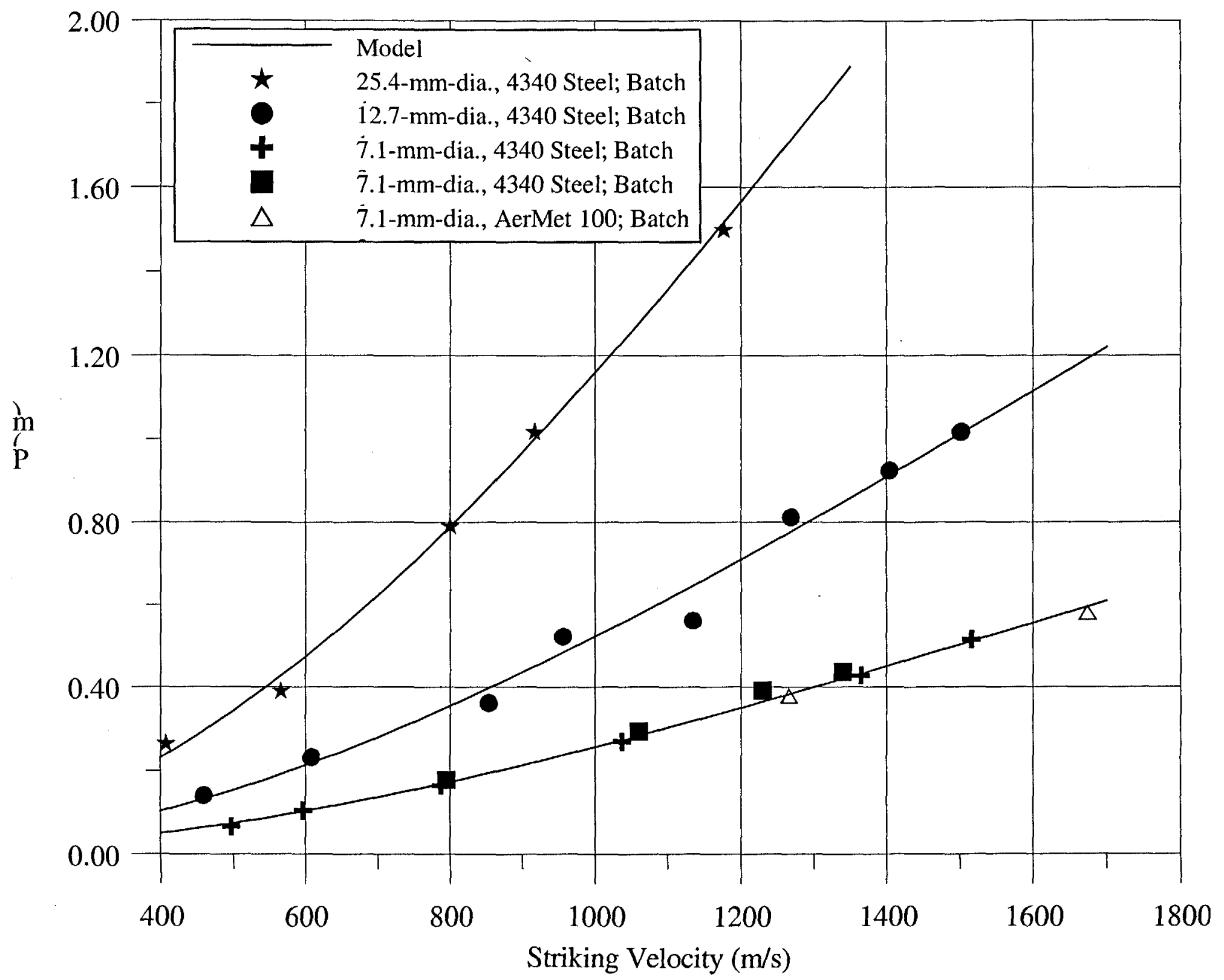

Figure 4. Data and model predictions for limestone targets 